ELORE (ISSN 1456-3010), vol. 16 - 2/2009.

Julkaisija: Suomen Kansantietouden Tutkijain Seura ry.

[http://www.elore.fi/arkisto/2_09/katsart_kaivola_2_09.pdf]

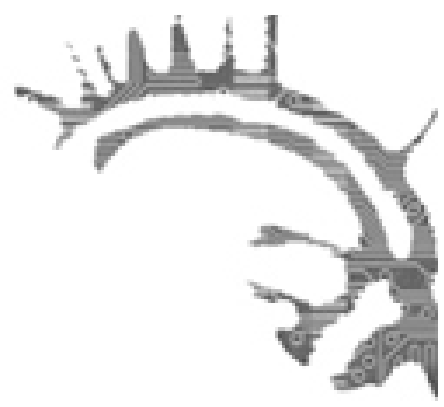

\title{
KATSAUSARTIKKELI
}

\section{KESKUSTELEVA JA ESIINTYVÄ KERTOJA}

\section{$\underline{\text { Annikki Kaivola-Bregenhøj }}$}

Tarkastelen katsausartikkelissani, milloin tutkijan havainnoitavissa oleva suullinen perinne muuttuu esitykselliseksi. Rajaan pohdintani folkloren kenttään enkä mene esimerkiksi politiikan, uskonnon tai esittävän taiteen areenoille. Keskiössä ovat omat haastatteluaineistoni ja kertomusperinne, mutta teen hyppäyksiä myös muiden lajien puolelle. Kysyn milloin voidaan puhua esitykesestä, milloin esiintymisestä ja mihin sijoittuu performanssin käsite.

Esitys on niin tavallinen ja jopa arkipäiväinen suomen kielen sana, että sen merkitys tuntuu itsestään selvältä. Sitä onkin käytetty paljon ja tuntomerkkejä määrittelemättä. Lauri Honko kirjoitti vuonna 1980 Kalevalaseuran vuosikirjan teemanumerossa Kertojat ja kunlijat: "Kaikki folkloren käyttäjät ovat tavan takaa esittäjiä: vitsin kertominen ja sananparren tokaiseminen on jo esitys." Ajatus siitä, että olisimme "tavan takaa esittäjiä" herättää minussa vastustusta - ehkä siksi, että käsityksemme folkloresta on vähitellen muuttunut niin, että me emme rajaa sitä yhtä selviksi lajeiksi tai ilmaisutyypeiksi kuin aikaisemmin. Niin vitsi kuin sananparsi voivat olla esityksiä, mutta kyse on usein myös sellaisesta perinteen käytöstä muun puheen virrassa, mikä ei nouse esittäväksi. Honko onkin halunnut vetää rajan arkistoidun perinteen ja käytössä olevan, elävän perinteen välille korostaessaan erityistä tilannetta, "jossa perinne on ainakin hetken avoinna empiiriselle tarkastelulle" (Honko 1980, 30). Olen itse käyttänyt esitys-termiä kirjassani Kertomus ja kerronta (Kaivola-Bregenhøj 1988), missä nimesin saman kertomuksen eri aikoina tehdyt nauhoitukset esityksiksi; englanninkielisessä versiossa käytin variant-termiä. Olen aina vierastanut termiä toisinto, koska se tuo mieleeni mekaanisen toistamisen, olkoonkin että se sopii joidenkin lajien - kuten vain vähän muuntelua sietävien arvoitusten - kohdalla käytettäväksi. Esitys-termiä käyttäessäni en ottanut kantaa siihen, oliko kuulemassani kerronnassa tuntomerkkejä, jotka tekivät siitä esityksellistä. Nyt haluan tarkentaa näkökulmaani ja miettiä, löydänkö haastatteluistani erityyppisiä kerrontoja, ja onko tällaiseen erittelyyn tarvetta. 


\section{AnNIKKI KAIVOLA-BREGENHø]}

\section{FOLKLORE ESITYSTILANTEESSA}

On selvää, että folkloren lajit voidaan erotella toisistaan myös esityksellisesti (Abrahams 1981). Kun tutkimme meistä ajallisesti etäällä olevia lajeja, kuten kalevalamittaista epiikkaa, olemme kaukana niistä tilanteista, missä tutkijat tapasivat runonlaulajia ja kuuntelivat heidän laulantaansa. Kun runotoisintoja ja niitä kehystäviä vähäisiäkin kontekstitietoja lukee tarkoin, on mahdollista löytää tietoa jopa 1800-luvun esitystilanteista. Lotte Tarkka on nostanut tutkimusaineistoistaan esiin kuvauksia niin eläytymiseen, haltioitumiseen, kyyneliin kuin nauruunkin päättyvistä kommunikaatiotilanteista, jotka hän nimeää performansseiksi (Tarkka 2005, 130). Ymmärrän termin käytön niin, että runon tallennustilanne muuttui esittäväksi, ja laulaja alkoi sanelun sijasta esiintyä ja sai tutkijan osallistumaan tapahtumaan intensiivisesti myötäeläen. Joskus keräään ja maineikkaan laulajan, kuten Arhippa Perttusen, kohtaaminen latautui "ilmapiirillä, joka on saattanut korostaa esityksen luonnetta performanssina" (Tarkka 2005, 101). Jokainen haastattelu on kohtaamistilanne, jonka virityksestä niin muistiinpano kuin haastattelunauhakin kertovat - on vain löydettävä analyysin avaimet.

Toinen esimerkkini on arvoitusperinne, jolla on selkeästi esityksellinen luonne. Tapahtumalle on jopa oma terminsäkin: arvuuttelu. Arvoituksilla on useita alalajeja, mutta tavallisin on ollut varsinainen arvoitus, jolle tyypillistä ovat alkusointu, kalevalamittainen säkeen rakenne ja metaforisuus ('Musta härkä mulleroinen, syö puita sylillisen, juo vettä korvollisen. - Saunan kiukoo.”). Tämän päivän elävää arvoitusperinnettä edustaa arvoitusvitsi, joka käyttää suoraa kysymyslausetta ja päättyy humoristiseen vastaukseen ("Miksi maalari sai potkut? - Hän liimasi tapetit päin seiniä."). Yhteistä näille hyvinkin erilaisille arvoitusgenren ilmentymille on kielen monimerkityksisyys, ja se että arvuuttelu on interaktiota, kysyjän, vastaajan ja mahdollisen yleisön vuorovaikutusta, jonka välineenä on kieli. Arvoitusvitsien kysely saattaa olla tilanteena nopeastikin ohimenevä ja lapset voivat päätyä siihen kun eivät keksi muutakaan tekemistä (Kaivola-Bregenhøj 2005, 292-334). Eroottissävyiset arvoitusvitsit ovat aikuisten suosima genre.

Arvuuttelusta löytyy eri puolilta maailmaa kuvauksia, jotka kertovat tarkasti säädellystä osapuolten välisestä kilpailusta esimerkiksi osana hää- tai ruumiinvalvojaisrituaalia (Kaivola-Bregenhøj 2001, 92-118). Ainutlaatuinen arvoitusten esitystapahtuma on Hymylän matka, epäonnistuneen arvaajan rangaistusnäytelmä, joka tapahtuu kuvitteellisessa nurinkurisessa maailmassa, missä kaikki on toisin. Esiintyjiä ovat sekä huono arvaaja että arvuuttelun muut osanottajat. Matka ja Hymylän oudot tapahtumat verbaalistetaan tähän tapaan:

Juo siellä pieni poika velliä vadista lattialla. Arvaaja kysyy talon munta väkeä ja
saa vellinlopun vadista pän pläsiänsä vastankseksi. Sünä tulee sitten emäntäkin ja
poika tai tyttö pyytää kasvojen pesuvettä, emäntä neuvoo bäntä peseytymään sak-
kasaavissa ja kuivaamaan hevosloimiin. Sitten kysyy Hymylän väki mitä munalle
kunlun nykeyään, eikä vieraalla ole munta kerrottavaa kuin nuo arvaamatta jääneet
arvoitukset. Silloin Hymylän väki nauraa moiselle tyhmälle töllikälle. Ja lähettää
vieraan takaisin. (Kiikek. Hilkeka Kesti KT 21:18.1936) 
Arvaaja palaa Hymylän kuvitteellisesta maailmasta takaisin kommunikaatiotilanteeseen, missä häneltä kysytään: "Mitä Hymylään nyt kuuluu?" Palaaja voi kertoa matkastaan "mitä mieleen muistuu" ja oikeat vastaukset antamalla lunastaa jälleen paikkansa arvuutteluyhteisössä, jonka hyväksyvä nauru korvaa epäonnistumisen häpeän. "Hän pääsee nyt vuorostaan arvuuttajaksi ja voi se, joka hänet viime kerralla toimitti Hymylään, päästä sinne itse!” (Kiikka. Hilkka Kesti KT 21:18.1936)

Äkkiä voisi tuntua siltä, että arvoitusvitsien kyselytilanteen ja Hymylän matkaa edeltävän arvuuttelun välillä ei ole mitään yhteistä. Niitä yhdistää kuitenkin siirtymä arvoitusten lajityyppiseen puhetilanteeseen, missä arvoitusten kyselylle luodaan kehys. Käytän tässä Richard Baumanin termiä "frame", jolla hän viittaa niihin keinoihin, joiden avulla varmistetaan se, että yhteisön jäsenet tunnistavat esityskehyksessä olevan kommunikaation performanssiksi (Bauman 1992, 45). Kehys valmistaa tilaa tulevalle arvuuttelulle, ja kuulija ymmärtää, mitä on tulossa (Palmenfelt 2009, 6 [online]). Lasten kohdalla kehystykseksi riitti lyhyt mitä tehtäis -tyyppinen kysymys. Varsinaisia arvoituksia kyseltäessä taas päätettiin, montako arvoitusta sai vastata väärin ennen kuin joutui rangaistavaksi. Arvuuttelulle on ominaista myös se, että arvoituksia on kysytty sarjoina. Joskus yksittäinen arvoitus on voitu upottaa muuhun keskusteluun ja tavanomaisesta poikkeava kysymys onkin sitten hämmentänyt kuulijan. Arvoitusten keruukilpailuun vuonna 1967 osallistunut Helmi Mäkelä muisteli kokemaansa:

\section{Olin nuori tyttö ja kehräsin villoja. Tuomiahon Maija tuli meille ja sanoi minulle "Karvanen reirellä makaa kattoo koska reikähä pääsöö". Loukkaannuin tästä kun se nä̈n rumasti sanoi (en buomannut sitä arvoitukseksi). Äiti buomasi sen ja sanoi "Siinähän se on sylissäs." Sitten minä vasta boksasin. (SKS KRA. Kuortane. Helmi Mäkelä AK 12: 467.1967.)}

Koska Maijan ja Helmin kohtaamisessa ei mikään kehystys osoittanut, että oltiin siirtymässä arvuutteluun, Helmi ei tunnistanut kuulemaansa lausetta arvoitukseksi vaan loukkaantui. Arvoituskysymysten seksuaalisesti värittyneeseen metaforastoon liittyy aina viaton vastaus (tässä kehruuta odottava villalepere), ja näin kuulijat välttyvät nolostumiselta. Seksuaalikuvastolla on arvuuttelutilanteissa kuitenkin eroottista tunnelmaa nostattava tarkoituksensa, olipa vastaus miten viaton tahansa.

Samakin folkloren tuote - esimerkiksi laulu - voi tilanteesta ja funktiosta riippuen olla työnteon tahdittaja tai kuunneltavaksi tarkoitettu esitys. Carsten Bregenhøj kertoo haastattelemastaan tanskalaisesta laulajasta Ida Hansenista, joka kuvaili työntekoa myötäilevän laulamisen itsestään selvyyttä sanoen: ’Se tulee niin kuin nälkä!” (Bregenhøj, suullinen tiedonanto syyskuussa 2007). Richard Bauman nostaa esiin merimiesten laulun, joka koordinoi työntekoa laivan kannella ja on vasta toissijaisesti laulutaidon näyte. Jos sitten samat laulajat ovat mukana meri-teemaisessa kansanjuhlassa, heidän laulunsa on esiintymistä. Silloin esityksellisyys nousee ohi laulun muiden funktioiden (Bauman 1992, 44).

Jos tartun nyt Richard Baumanin performanssi-määrittelyyn, jonka mukaan performanssi on kommunikatiivisen käyttäytymisen muoto, mibin liittyy esteettinen lataus, kebystys ja esillepano kuulijakuntaa varten, niin Hymylän matka -tilanteesta löytyvät performanssin 


\section{AnNIKKI KaIVOLA-BREGENHøJ}

tuntomerkit (ks. Bauman 1992, 41). Kuulijakuntana on koko se joukko, joka arvuutteluunkin osallistui, ja tilanteen avaa kehystys, jossa sovitaan miten monta kertaa arvaaja voi epäonnistua. Ja edelleen: "Kun sitten tuli jonkun 15 [arvaamatta jäänyttä arvoitusta] jo täyteen, niin luetteli arvuuttaja kaikki ne arvoitukset, joista hän tuomittiin sitten Hymylään. Tuo tyhmä arvaaja puettiin nyt hullunkuriseksi suuri takki tai pälsyt nurinpäin isot toppitallukkaat tai muuta sellaista laitettiin päälle. Ja sitten hän lähti Hymylään, jossa ei kuu kumota eikä päivä paista.” Arvoitusvitseistäkin voidaan löytää esteettinen lataus (esimerkiksi vastakkainasettelu, odotuksenvastaisuudella ja monimerkityksellisyydellä leikittely), mutta niiden kysely ei ainakaan kahdenkeskisessä arvuuttelussa ole esiintymistä. Rajanveto perinteen käytön eri muotojen välillä on tehtävä tilanne tilanteelta. Edellä mainitut lauluesimerkit taas kertovat siitä, että performanssi ei ole sidoksissa lajiin vaan sen toisistaan poikkeaviin käyttöyhteyksiin.

\section{MONI-ILMEINEN KERRONTA: PUHEESTA PERFORMANSSIIN}

Jos ajattelemme sellaista kerronnallisten puheilmaisujen skaalaa kuin keskustelu, raportoiva kuvailu, esitys ja esiintyminen, niin kaikissa näissä lajeissa voi olla mukana folklorenomaisia piirteitä, mutta silti ne kaikki eivät ole esittäviä. Eivät ainakaan aina. En kuitenkaan keskity tässä yhteydessä erittelemään raportoivan kuvailun lajeja, joita Laura Aro on analysoinut (Aro 1996, 65).

Kertomusta ei koskaan toisteta täysin samana. Kun se on toistuvasti käytössä, kerronnan eri tasoilla ilmenee variaatiota. Kyse ei ole kertojien muistisuorituksen puutteista vaan siitä, että esimerkiksi tarina kerrotaan aina kulloisellekin kuulijakunnalle, ja näin kertojan mielessä olevista tarpeista luodaan joka kerran hieman erilainen kokoonpano. Dell Hymesin käsittein kyseessä on kertomiseen liittyvä kerronnallinen kompetenssi ja sen toteutumana esiin tuleva performanssi (Hymes 1975). Lauri Honko nimeää kerrontaprosessin "luovaksi tuottamiseksi" (Honko 1980, 30). Puhun itsekin mielelläni tuottamisesta, koska se korostaa tässä-ja-nyt tapahtuvaa kertomuksen kokoamista tilanteeseen sopivista niin sanallisista kuin oheisviestinnän elementeistä. Kertoja ei ole levyä kerta kerralta soittava automaatti vaan onnistuessaan ja epäonnistuessaankin luova ihminen.

Tarkastelen ensin keskustelunomaisen, raportoivan kuvailun ja esityksen tai esiintymisen eroa. Haastattelutilanteessa hyvin suuri osa puheesta on osapuolten välistä keskustelua, joka ei ole esittävää. Kun kerrontaprosessi on kauimpana esiintymisestä, sitä leimaavat kysymys-vastaus -rakenne, haastateltavan tapailu ja sanojen etsintä, mahdollinen haluttomuus tai velvollisuudentuntoinen osallistuminen. Tai sitten se voi olla useamman keskustelijan innokastakin mielipiteiden vaihtoa, mitä leimaavat sekä vuorottelu että päällekkäin puhuminen. Tuloksena voi olla paljon tietoa, mutta haastattelija ei tunne seuraavansa esiintymistä sen paremmin kuin esitystä pienelle kuulijakunnalle. Esimerkiksi muistitietohaastattelujen kohdalla suuri osa puheesta on "vapaamuotoista asioiden, ihmisten, olosuhteiden ja tapahtumien kuvailua" (Ukkonen 2000, 113). Kuvailuun limittyy myös kiinteämuotoisia kertomuksia, jotka osoittavat, "minkälaiset asiat ja/tai tapahtumat ovat kertojan näkökulmasta niin tärkeitä tai 
mielenkiintoisia että niitä muistellaan kokemuskertomuksina" (Ukkonen 2000,128). Taina Ukkonen ja Matti Suojanen ovat osoittaneet, että ihmisten tavalliseen arkeen ei sisälly paljonkaan varsinaisia kertomuksia. Pelkkä ihmisten yhdessäolo ei tuota kertomuksia, sillä "narratiivisuus vaatii tilanteita, joissa sanallinen viestintä hallitsee ja joissa on sopivia sytykkeitä: aiheita, yleisöä, tarkoituksia ja kertojia" (Suojanen 1996, 122).

Haluan taas tuoda esille Inkerissä 1992-1993 haastattelemani Lenaksi kutsumani naisen, jonka kerrontaa olen aiemminkin analysoinut (Kaivola-Bregenhøj 2006, 38-41; 2007, 189-193). Siteeraan alun Lenan pitkästä raportoivasta kuvailusta, johon mahtuu monia kertomusaihioita ja kokemuskertomuksia. Kursivoin avainsanojen tiheän toiston, jonka avulla Lena kuljetti nopeasti etenevää kerrontaansa:

(Annikki Kaivola-Bregenhøj): Voitteko työ kertoo vähän elämänvaiheitanne.

(Lena): Niinko et mite oikei elettii sota-aikan ja enne sottaa?

(AK-B): Nii ja ennen sottaa ja sitte sen jälkeenki.

(Lena): Vot, enne sottaa myö elettii täs koton. Tul se sota, ei peästy peril, mitä siint tulloo siint soast. Mitä se tulloo. Lähettii metsää kaik pakkoo. Metsää otettii lehmät kaik ja lähettii metsää. Metsäs siel jo ammuttii. Käytii ampumaa jo kaik. Syötii tattiloi siel ja lypsettii sitä lehmii. Miul jäi lehmä [epäselvää]. Lehmän jäti sin. Läksimmä et tänne tulloo kuolema metsää, nälkä. Läksin Leningrattiin. Leningratis olin siel. Lehmät annoin köyhil ihmisil. Meil ol yks nainen, häl ol viis lasta. Lehmän annoin hänel.

(AK-B): Ketä ne oli, jotka ampu siel metsäs?

(Lena): Suomalaisii [epäselvää]. A sit jo Saksa tul likel ja venäläisii tulloo, ruumiit kannetaa jo Saksa. Mie poikkee läksin sielt. Äit jäit sinne, veikko ja sinne siso. Kaik jäit metsää, isä.

(AK-B): Miten kauan työ olitte siel?

(Lena): - - [epäselvää] tuas pakkoo sinne. Tuas takas mänem metsää. Mie mänil linnaa. Olin siel linnas, ko viel sai vähä syyvä. A sit leipä tul kortil. Kaikil annettii kortit. Miul ei ole korttii. Mie tulin jalkasii, Leningratist jalkasii kottii. Iespäi leipää säkki, takanpäi leipää säkkiki kannoin. Tulee vähän aikaa. Tuas viijää ne venäläiset läks tappaa. Mihi sie mänet Saksa vastaa? No tulin kottii iltasil. Ei ole ketään kyläs. Lämmitin tuon tätin kiukaan, oman kiukaan. Nyt leipää leikkaamaa, suhharloi tekemää, kuivamaa leipää - -" [jatkuu]

(Nauhoitus on tallennettuna SKSÄ:ssa, mutta en anna nauhaviitettä kertomuksen yksityisyyden takia.)

Lena otti tavatessamme johdon käsiinsä ja veti minut heti ja ehdoitta omaan kokemusmaailmaansa. Lenan puhetempo oli hektinen: sanat putosivat toistensa päälle. Kerronta kuulosti melko kaoottiselta, mutta kun olen kuunnellut ja lukenut sitä useita kertoja, sieltä nousevat selvät kerronnan keinot esille. Tarkoitan tässä kerronnan keinoilla esimerkiksi rakenteellisia ratkaisuja, mielekkääksi paljastuvaa toistoa, joka auttoi Lenaa siirtymään tapahtumasta toiseen, voimakkaita verbejä ja filminomaisten kohta- 


\section{AnNIKKI KaIVOLA-BREGENHøJ}

usten rakentumista, jotka jäsentävät kerrontaa. Olen ajatellut, että kaoottisuus onkin Lenan kuvauksen voima. Se kertoo sekasortoisten tapahtumien päällekkäisyydestä sekä tapahtumiin liittyvistä ristiriitaisista tunteista, joita Lena ei verbaalista. Tämä raportoiva kuvailu on kokemuskerrontaa, mutta kaukana esiintymisestä. Olen Taina Ukkosen $(2000,39)$ kanssa samoilla linjoilla: " - - kokemusten kerronta ei tarkkaan ottaen ole sama asia kuin kokemuskertomusten esittäminen (kursivointi AK-B)." Tällä Ukkonen tarkoitti sitä, että kokemuksia voi "kerrata ja kertoa ilman että on muokannut niitä rakenteeltaan kertomuksiksi” (Ukkonen, sähköpostikeskustelu 2008). Lenan ratkaisut eivät ole nopeasti etenevässä puhetilanteessa tietoisia, mutta ne osoittavat, että hänellä oli hallussaan kerronnallinen kompetenssi. Kerronnan funktioista informatiivisuus ja uskoutuminen veivät voiton esityksellisyydestä. Lena oli syvälle uppoutunut oman kokemuksensa maailmaan, hän oli siellä ja kertasi ja tulkitsi tapahtumia. Samalla hän piti minuun tiivistä katsekontaktia kuin tarkkaillakseen pystynkö minä seuraamaan häntä hänen kokemusmaailmaansa.

Lenan pitkässä kertomuksessa on monia kansanomaisen estetiikan keinoja, mutta en silti pidä sitä performanssin kaltaisena esiintymisenä, koska kehystys ja esillepano kuulijakuntaa varten puuttuvat. Kertomus oli kohtaamistilanteemme ensimmäinen, ja Lena syöksyi voimalla purkamaan kokemustaan, mistä oli kulunut jo puoli vuosisataa. En ole koskaan voinut ymmärtää, miksi hän kertoi tuntemattomalle ihmiselle elämänsä keskeisimmän kokemuskertomuksen heti tavatessamme. Mutta tuntemattomalle oli helppo purkaa traumaattista kokemusta, joka kuului aiemmin varottaviin puheenaiheisiin. Lena ei esittänyt kertomusta vaan eli sitä.

Haastattelutilanteen raportoiva keskustelu voi aika ajoin leimahtaa esittäväksi kerronnaksi, jota luonnehtivat haastateltavan spontaanit irtiotot, innostuneisuus ja ilmiömäinen halu kertoa. Valitsen tähän Juho Oksasen monista kertovista esityksistä pienkertomuksen, jolle annan nimeksi Papit ja politiikeka.

(Jubo Oksanen): Piispakin ku män alttarille, silloi ku kuninkasta Suomee hajettii. 'Ei tasavaltalaine ballitusmuoto ei ole Jumalan mielen mukaine ballitusmuoto. Kuninkas, kuninkaskunta, sejärjestys, se oj Jumalam mielem mukainen ballitusmuoto.' (Pekeka Laaksonen): Sano piispa?

(JO): Piispa alttarilla.

(Annikeki Kaivola): Kukas piispa se oli?

(JO): En san nimejä. Kyllä mä kuulin sen. Em min, mäs sanoon en.

(PL): Ottiks ne muuten noim politiikekaa noi papit yleensä osaa?

(JO): Rovasti löi nyrkkisäs soarnastuolil laitaaj ja sano: 'Taistelubansikas ov viskattu vastek kasvoja. Vieläkö bäpeällisempätä? Sosialidemokraatti ov valittuk kirkollisministeriksi.' Sütäs sen kuulit. [nauraa] Nyt loppu.

(SKSÄ 353:28-29.1969.)

Juho Oksasen esityksessä kuuluu papillisen hurskaan saarnanuotin imitointi, tai suorastaan parodiointi, missä on hyvin selviä äänen korkeuden ja voimakkuuden vaihteluita. Jotkut sanat Oksanen sylkee voimalla suustaan. Imitoinnin tarkoituksena oli korostaa sitä, miten papisto käytti hengellistä valtaa hyväkseen halutessaan ajaa 
muita, eli tässä tapauksessa poliittisia tarkoitusperiään. Ei ole epäilystä siitä, etteikö tässä olisi kyse tietoisesta esiintymisestä.

\section{SANATON ESITYS JA VAIENNETUT ESIINTYJÄT}

Siirryn hetkeksi kertomusten verbaalista maailmasta sanattoman tai vähäsanaisen kiertueperinteen maailmaan. Kun lapset lähtevät nuutinpäivän iltana naamioituneina kiertämään talosta taloon, he ovat mukana vuosittain toistuvassa paikallisperinteessä, mikä on joulun loppumisen merkki. Mukana on kaksi osapuolta, ja niin naamioituneet kuin katsojatkin tietävät omat roolinsa. Lapset tietävät, että he eivät saa paljastaa keitä ovat, ja he joko elehtivät mykkinä tai tavoittelevat ääntään muuttaen hullunkurisia vastauksia heille heitettyihin kysymyksiin. Katsojat tietävät, että heidän pitää yrittää kysymyksin ja yksityiskohtia tarkkaillen paljastaa, kuka naamion takana on. Osapuolten kohtaaminen viehättää niitä, jotka tuntevat tradition, ja paikkakunnalta muuttaneet voivat tulla kiertue-illaksi kotipuoleen tapahtumia seuraamaan.

Kun aikuinen mies pukeutuu naiseksi ja tanssii tangoa nuutinillan kylätansseissa miehen tai mieheksi pukeutuneen naisen kanssa, hän on lähtenyt esiintymään. Hän on panostanut rooliinsa pukeutumalla ja meikkaamalla, ja hän esittää tietoisesti naista sellaisena kuin hän kokee naisen olevan. Esiintymiseen kuuluu flirttiä ja keimailua, ja siinä voidaan liikkua uskottavuuden rajoilla. Parodian puolelle ei mennä, koska silloin liki-toden lumous särkyisi ja esiintyminen menisi pilalle. Paikalla on yleisöä, ja kyse on julkisesta viihteestä, mitä kuka tahansa paikalle osuva voi tulla seuraamaan. Kaikki tuntevat pelin säännöt, kuten sen että nuuttipukkiin ei saa koskea. Paikallislehdessä ollut tieto nuutinillan tansseista luo esiintymiselle julkiset puitteet. Yleisö kommentoi tanssia, joko ääneen tai pienryhmissä naureskellen ja arvaillen "naisen" todellista identiteettiä. Täydelliseen onnistumiseen kuuluu se, että kukaan ei tunnista kaunotarta naapurikylän mieheksi, ja että tämä voi purkaa vielä vuosienkin jälkeen tunnelmiaan sanoen: "On nautinnollista esittää kypsää, rohkeaa naista." Tämä tietoinen ja suunniteltu esiintyminen tuotti niin huvia kuin iloakin.

Jos spontaaniperinnettä aletaan järjestellä esitykseksi, kaikki voikin epäonnistua. Näin kävi nuutinillan aikaan vuonna 1973, kun Carsten Bregenhøj ja minä autoilimme Keikyän pikkuteitä nuuttipukkeja etsiskellen. Me tavoitimmekin heidät, ja ilahtumisemme oli suuri, kun ensimmäiset naamioituneet lapset osuivat pimeällä kylätiellä auton valokeilaan. Perinne eli! Saamamme vihjeen perusteella olimme oikeilla kylillä ja pääsimme antoisan ja vuosia jatkuvan kenttätutkimuksen alkuun. - Mutta seuraavana iltana meidän oli käytävä naapuripitäjässä, minne Kansanrunousarkistosta oli sovittu tutkimusryhmän tulo. Me olisimme halunneet luottaa spontaaneihin löytöihin, mutta olihan lupaus lunastettava. Jokin oli kuitenkin mennyt vikaan, sillä sovitussa paikassa oli koolla monikymmenpäinen nuuttien joukko odottaen Helsingistä tulevia TV-kuvaajia. Tosiasiassa nuutinillan kiertueperinne vaatii kaksi osapuolta: naamioituneet ja asiansa osaavan yleisön. Jos vanha asumaton museorakennus lavastetaan näyttämöksi ja huhu kertoo TV:n olevan paikalla, ei spontaanista ja pelin säännöt tuntevasta perinteestä ole tietoakaan. Kaikki haluavat esiintyä, mutta kukaan ei muuttuneessa tilanteessa tiedä 


\section{AnNIKKI KaIVOLA-BREGENHøJ}

miten toimia. Yleisö puuttuu ja sen mukanaan tuoma vastavuoroisuus, ja kenelläkään ei ole hauskaa. Ilta on auttamattomasti pilalla.

Esiintyminen ei ole aina täysin vapaaehtoista ja voi sen takia epäonnistua. Ajattelen tässä runonlaulajia, joita tuotiin sivistyneistön kummasteltaviksi laulujuhlille. Seppo Knuuttila on kuvannut tilannetta osuvin sananvalinnoin: esiintyjï "värvättiin" juhlille, missä heiltä edellytettiin "vakaata, hiljaista ja vaatimatonta käytöstä". Vuotta 1896 on pidetty "runonlaulajien, kanteleensoittajien ja itkijöiden julkisuuteen tulemisen ja kultin käännekohtana" (Knuuttila 1989, 220). Tavaksi tuli, että esitysten kestoa ruvettiin rajoittamaan. Martti Haavio kuvaa tilannetta näin: ’Uroot kun pääsivät laulunpäähän kiinni, eivät olisi raaskineet lopettaa, vaan täytyi heille pari kertaa ilmaista, että aika oli rajoitettu (Haavio 1948, 208)." Virallinen Suomi on rakastanut esiintyviä kansanperinteen taitajia, ainakin niitä, jotka ovat päässeet julkiseen hyväksyntään. Tuskin meillä muuten olisi Larin Parasken patsasta, joka esittää karjalaisen itkijänaisen perikuvaa sellaisena kuin kuvanveistäjä on halunnut hänet nähdä.

\section{ESIINTYVÄ KERTOJA}

Kertojan esityksestä pienelle kuulijakunnalle tai haastattelijalle voi olla vain harppaus julkiseen esiintymiseen. Juho Oksasen kertomus Papit ja politiikka voisi aivan hyvin sopia esiintymisnumeroksi ja mene tiedä, vaikka hän olisi sitä esittänytkin, jos ei suurelle julkisuudelle, niin kyläkunnan yhteisissä tapaamisissa. Oksanen tiedettiin yhteisöissään kertojaksi, näin vakuuttivat minulle kartanon rouva ja taksikuski, joilta kyselin sopivia haastateltavia.

Esiintyjät voi jakaa satunnaisesti esiintyviin ja niihin, jotka pyrkivät kehittämään esiintymisestä ammatin. Juho Oksasesta tiedettiin, että hän käytti satunnaisesti mutta mielellään valmisteltuja puheenvuoroja erilaisissa juhlatilaisuuksissa. Kun hän sai Kalevalaseuran tunnustuspalkinnon, hän piti Kekrinpäivän juhlassa onnistuneen kiitospuheen. Helsinkiläisprofessorien seura ei häntä pelottanut, päinvastoin, se antoi pontta esiintymiselle. Marina Takalo puolestaan alkoi kertoa tädiltään oppimiaan satuja ensin oman lähipiirinsä ulkopuolella tukinajomatkoilla. Kerronta-aikaa olivat illat, jolloin ruokailun jälkeen levättiin ja kuivateltiin vaatteita. Siellä Marina Takalo oppi myös veljiltään ja serkultaan satuja, joita ei kotikylällä tullut kerrottua. Tilapäistöissä mukana ei ollut niitä vanhempia ihmisiä, joita pidettiin niin osaavina sadunkertojina että nuorempien oli parasta olla vaiti. Vasta evakkomatkan aikana itärajan takaisesta Oulangasta Suomeen Marina Takalo alkoi esiintyä julkisesti "Kuusamon miesten suosimana sadunkertojamestarina". Hän totesi, että "Iltasatu on ajanvietettä väsyneille kulkijoille" (Pentikäinen 1971, 325-327). Esittäjästä tuli esiintyjä tilanteen niin vaatiessa ja tehdessä sen mahdolliseksi: niissä tilanteissa oli varmaan selkeä performanssin luonne. Myöhemmin Suomessa Takalo esitti satujaan useimmiten perhepiirissä. Marina Takalon kohdalla on nähtävissä se, että sama ihminen sopeutuu esiintymistilanteen keskipisteeksi ja pienen piirin kertojaksi.

Linda Dégh on korostanut sitä, että sadunkertojan on ensin saavutettava sellainen asema, että hän kykenee voittamaan kuulijakunnan kiinnostuksen. Usein juuri kylän 
ulkopuolinen työyhteisö antoi kertojalle tilaisuuden kasvaa esiintyjänä (Dégh 1969, 88). Galit Hasan-Rokem tunsi sadunkertojan, jonka oli esiinnyttävä salaa, koska hänen miehensä ei sallinut hänen kertovan satuja. Nainen mursi pakollisen vaikenemisensa kerran vuodessa matkustaessaan uskonnolliseen juhlaan toiselle paikkakunnalle. Näiden matkojen aikana hän esiintyi sinä dramaattisena kertojana, joka hän todellisuudessa oli. (Hasan-Rokem, suullinen tiedonanto syyskuussa 1981.)

Ammattimaisista kertojista meillä on tietoa esimerkiksi savottayhteisöistä. Urpo Vento on löytänyt kuvauksen kämpän viihdyttäjästä, tuberkkeliarpisesta, hoikasta, heikosti pukeutuneesta miehestä, joka "pyysi saada ylöspitoa vastaan jäädä kämpän viihdyttäjäksi savotan ajaksi!. Sovittiin, että

[v]ïhbdyttäjä ei saa tebdä siivous- eikä munta työtä, ei edes pestä ruoka-astioita. Vain päivällä, kun ei ole muita kämpällä, saa panna puita kaminaan. Hän ei saa kabta kertaa pubua samaa vitsiä eikë juttua erottamisen uballa. Jos samaa pubutaan kabdesti, asia otetaan heti kämppäkokonksen käsiteltäväkesi. - - Vajaan kahden kunkauden pä̈stä vïhdyttäjä vihdoin pubui jo ennen pubuttua. Kämppäoikeudessa Ville, se oli miehen nimi, vetosi henkisen työn raskauteen ja siihen, ettei bänelle ole järjestetty lomaa. Hän pyysi päästä Kuopion mark kinoille opiskelu-ja virkistysmatkalle. Kämppäoikeus hyväksyi puolustuksen ja päätti rybtyä keartuttamaan loma-ja virkistyskassaa ja bankekimaan varusteita matkaa varten. (Vento 1980, 97.)

Tämä katkelma sisältää ne tuntomerkit, jotka Richard Bauman nimeää klassikkoteoksessaan Verbal Art as Performance: siinä on sekä

1) taiteellinen toiminta (engl. artistic action), tässä tapauksessa viihdyttävä kertominen että

2) taiteellinen tapahtuma (engl. artistic event), eli performanssitilanne, jonka osatekijöitä ovat esiintyjä, tuote (engl. art form), kuulijakunta ja puitteet (engl. setting) (Bauman 1978, 4).

Mutta ei tässä kaikki, sillä jatkuessaan kuvaus kämpän viihdyttäjästä näyttää meille myös Villen esiintymisen olennaisimman funktion: suunsoittoa seuranneen naurun terapeuttisen vaikutuksen. Se oli elintärkeätä, sillä kuvaus loppuu näin:

Elinehtojen puolesta olimme sillä rajalla, että monet hirttivät itsensä. Neljän kuukauden aikana viihdyttäjä esitti ohjelmaa 2-4 tuntia illassa ja rokulipäivinä jopa 10 tuntia. Kaikki ymmärsivät Villen arvon. Hän sai hakkomiehen lopputilin ylittävän rahasumman, kun savotta loppui. Hattu kiersi miehestä mieheen. (Holtari ym. 1970, 301-304.) 


\section{Kertoja nOUSEE ESTRADILLE}

Kun esiintyjä nousee estradille - olipa se sitten tukkikämppä, kesäjuhla tai yliopiston auditorio - niin mitä tapahtuu tuotteelle? Nyt tarvitaan useita eri tilanteissa tallennettuja saman tuotteen esityksiä. Käytän esimerkkinä kertomusta ja Richard Baumanin analyysia Ed Bell -nimisestä Texasissa 1905 syntyneestä kalastusleirin omistajasta, joka alkoi 1980-luvulla esiintyä julkisissa tilaisuuksissa. Bauman keskittyy analyysissaan muutoksiin, joita Ed Bell teki repertoaarinsa keskiössä olleisiin liioittelukertomuksiin (engl. tall tale) sen jälkeen kun oli aloittanut julkisen esiintymisensä. On syytä käyttää ilmaisua "teki muutoksia", sillä tämä kertoja oli hyvin tietoinen siitä, että hänestä tuli ammattimainen esiintyjä. Jättiläismäisen puun uskomattomasta hunajamäärästä kertova "The Bee Tree" nauhoitettiin vuosina 1971, 1979 ja 1982, ja Bauman erittelee niissä tapahtuneita muutoksia. Jokaisen kerronnan kohdalla niin haastattelija kuin kertomuksen nauhoituspaikka vaihtuivat.

Muutoksista ensimmäinen ja silmäänpistävin oli se, että kerrontaan tuli lisää mittaa. Pisimmillään kasvu tiesi 82 prosentin lisäystä kertomuksen sanastossa (Bauman 1986, 81). Kertomukset kasvoivat, mutta juoni ei juuri muuttunut. Ed Bell totesikin, että on helpompi lisäillä jotakin kohtaa kuin muuttaa kokonaisuutta. Baumanin mielestä nämä lisäykset eivät ole täyteainesta vaan lujittavat kertomuksen rakennetta (Bauman 1986, 91-92). Toiseksi Bell lisäsi kertomuksen muotoon vaikuttavia ilmaisukeinoja, muun muassa parallelismia, minä-muotoa ja repliikkien käyttöä. Muutoksista nämä kaksi näkyivät selvästi myös Juho Oksasen kerronnassa, kun haastattelin häntä useita kertoja ja hän alkoi jollakin tasolla työstää kertomuksiaan.

Kolmas ja huomiota herättävin Baumanin kirjaamista muutoksista oli metakerronnan lisääntyminen. Kyseessä ovat kertomusta (esimerkiksi sen sanomaa, lajityyppistä muotoa tai funktiota) tai kerrontatapahtumaa (esimerkiksi osanottajia tai toimintaa) koskevat kommentit. Niiden avulla Ed Bell muun muassa otti kantaa kertomuksen uskottavuuteen tai selitti tapahtumien kulkua. Erityisen kiintoisia ovat kuulijoiden puhuttelut ja sananvalinnat, joiden avulla hän otti kuulijat mukaan kerrontatilanteeseen. Metakerronnan avulla hän rakensi siltaa kerrotun tilanteen ja kerrontatilanteen välille. Kyse oli yhteisöllisen vuorovaikutuksen lisäämisestä. Kertomuksen alussa ja lopussa tällaisten ilmausten avulla on mahdollista siirtyä kerrontatilanteesta kertomuksen aikaan ja tapahtumiin ja jälleen takaisin. Tämänkaltainen metakerronta oli tyypillistä myös Juho Oksasella, joka alkoi toistuvien haastattelujen myötä kommentoida esimerkiksi tapahtumien uskottavuutta tai paikallishistoriallisten kertomusten henkilöitä.

Neljänneksi tulivat kerronnan yhteisölliseen kontekstiin liittyvät muutokset. Nuorena Ed Bell oli yksi kertoja muiden joukossa metsästys- ja kalastusmatkojen nuotiotulilla. Kaikki osallistujat tunsivat kulttuurissaan käytetyt kertomukset, ja osa heistä oli kertojia itsekin. Silloin kukaan ei voinut pitää hallussaan vuoroa liian kauan. Siteeraan Ed Belliä, joka sanoi: 'Tiedäthän, kun me tapailtiin kertoa näitä stooreja, niin me oltiin nuotiolla ja niin, sullahan ei ole paljonkaan aikaa jutun kertomiseen. Toiset kaverit odottaa siell, että nyt... nyt hän haluaa kertoa oman stoorinsa. Sun on tehtävä omastas niin lyhyt kuin voit, ja niin voit katkaista jokaisen oksanhaarakkeen mikä on tiellä ja mennä suoraan asian ytimeen. (Bauman 1986, 102)" Ed Bellin 
metafora oksistosta, joka on kerronnan etenemisen tiellä, osoittaa hänen tunteneen kertomustensa rakenteen ja pystyneen nopeisiin muutoksiin.

Kun Ed Bell alkoi esiintyä julkisesti, hänen kuulijakuntansa muuttui kaupunkilaiseksi eikä tuntenut sitä maalaiselämää, joka oli liioittelukertomusten oikea taustamiljöö. Jotta yleisö pystyisi vastaanottamaan kertomuksen, sen olisi hallittava kulttuurinen kertomusskeemasto. Mutta koska yleisöllä ei ollut lajikohtaista tietoa liioittelukertomuksesta ja sille ominaisista sisällöistä, se tarvitsi enemmän selityksiä ja yksityiskohtia. Liioittelukertomus alkaa kuin uskottavaksi tarkoitettu kokemuskertomus, mutta kun uskottavuus on venytetty äärimmilleen, kertomus paljastuukin puijaukseksi. Kertojan onkin panostettava liioitteluun (viimeisessä variantissa Bell kuvaa hunajan määrää näin: 'That honey, now folks, was still puorin' outa that six-inch hole, into Rock Water Hole Branch. And it was just f-f-f-fooooo in there like that [flowing gesture]." Ja kertomus päättyy codaan: "And folks, as far as I know that creek is still runnin' full with honey.") Koska Bell esiintyi nyt estradilla, hän joutui houkuttelemaan kuulijoita vastavuoroiseen osallistumiseen. Oli tarpeen käyttää esimerkiksi suoraa puhuttelua ('Well, folks, I'd like to tell you about this."). (Bauman 1986, 90, 103-104.)

Toisaalta, nyt ei ollut enää pakko kilpailla esiintymisvuoroista eikä puheajasta. Ed Bell tiedosti tämänkin ja sanoi: "Mulla ei ole huolta siitä että saisin ne kuuntelemaan. Voin kertoa...lisäillä niin paljon kuin katson tarpeelliseksi." Tämä ei tarkoittanut sitä, että kertomuksia voisi loputtomasti laajentaa, ja Bell oli kerronnan rajoista tietoinen. Hän ilmaisi asian näin: ’Joskus sä voit pitkittää hieman liikaa ja alat menettää ihmisten mielenkiinnon. Mutt jos vain jatkat ja jatkat niin pitkälle kuin mahdollista ja sitt paukautat jutun kärjen niiden eteen nopeasti” niin tulos on täydellisen tehokas. (Bauman 1986, 104.)

Ed Bellin uusi tyyli pysyi samana, esiintyipä hän sitten suurelle joukolle tai vain pienelle tutkijoista tai opiskelijoista koostuvalle kuulijakunnalle. Tämän hän teki, koska mielsi olevansa julkisesti esiintyvä kertoja, olipa kuulijakunta paikalla tai ei: haastatteluthan voitaisiin kuunnella myöhemmin, kuten tietysti tapahtuikin. Niin Bell muuttui ihmisestä, joka ei ollut ajatellut itseään kertojana, ihmiseksi joka tiesi olevansa huomattava kertoja ja aina vastuussa kykyjensä täysipainoisesta esillepanosta (Bauman 1986, 105-106). Olisiko yleisemminkin ottaen niin, että jos kertoja on luonut itselleen julkisen esiintyjän identiteetin, niin esiintyjästä ei enää tule pienen piirin esittäjää? Marina Takalolle se onnistui, mutta vastataksemme tähän yleisemmin tarvitsemme useita seurantatutkimuksia.

Kun esittäjästä tulee esiintyjä, hän "nousee estradille" (olipa se sitten esiintymislava tai kertojan roolinoton luoma tilanteen hallinta) ja on vapaa pienryhmässä tapahtuvan kerronnan paineista. Hän voi jalostaa julkiset kertojanlahjansa huippuunsa. Mutta samalla hän kohtaa vaikeuksia menettäessään sen vastavuoroisuuden, joka tuottaa pienryhmässä kertomuksen toisensa perään. Ajattelen, että vaikeuksia on ainakin neljä: Ensiksikin kertomuksen on ylitettävä niin kutsuttu kerronnallisuuden kynnys. Sen siis on oltava sisällöltään kuulijoita kiinnostava, sen komiikan on oltava osuvaa, sen on oltava käänteiltään uskottava, ellei se sitten tyylittele juuri uskottavuuden rajan ylityksillä, ja sen on oltava yksityiskohdiltaan mielenkiintoinen tai yleispätevä. Lisäksi sen on sovittava tilanteeseen. Jos kertomus ei vastaa kulttuurisia odotuksiamme, tai 


\section{AnNIKKI KaIVOLA-BREGENHøJ}

ainakin osaa niistä, se ei tavoita myötämielistä kuulijaa. Haastattelija kuuntelee, ehkä kaveripiirikin, mutta yleisö ei. Ei olekaan ihme, että Ed Bell turvautui metakerrontaan saadakseen kuulijat mukaansa. Toiseksi kertomuksella on oltava jokin huippukohta, ponsi tai kärki, joka liittyy niin kertojan kuin kuulijankin tuntemaan maailmaan (Polanyi 1989, 16). Julkinen esiintyminen tuntemattomalle kuulijakunnalle ei tee tätä helpoksi, koska vain poikkeuksellisesti kertoja ja kuulija jakavat saman maailman. Kolmanneksi kertomuksessa voidaan intiimissä esityksessä ilmaista erilaisin paralingvistisin keinoin, ilmein ja elein paljon enemmän kuin mitä kertomusteksti tuo esille (Siikala 1980, 92). Miten tämä onnistuu silloin kun intiimi kerrontatilanne muuttuu julkiseksi esiintymiseksi? Neljänneksi kuulijoiden kommentit, keskinäinen riitely ja jopa epäilevät tai pilkalliset huomautukset tuntuivat rohkaisevan esimerkiksi Linda Déghin tuntemia sadunkertojia. Ne olivat osoitus kuulijoiden aktiivisuudesta. "Kertomuksesta tulee kauniimpi ja värikkäämpi, kun kertoja tuntee kuulijoiden olevan mukanaan, elävän joka hetken yhdessä hänen kanssaan; mitä täydellisempi yleisön yhteistyö, sitä täydellisempi kertomuksesta tulee" (Dégh 1969,113-118). Kulttuuriset erot ratkaisevat, millaisen aktiivisuuden esiintyjä kokee rohkaisevaksi ja mikä häiritsee. Eroa syntyy myös pienelle piirille suunnatun esityksen ja julkisen esiintymisen välillä. Tähän viittaisi myös Ed Bellin lausuma nuotiotulien kerronnasta, missä vuoro oli jaettava muiden kertojien kanssa.

Olen halunnut vetää rajaa esitylesen ja esïntymisen välille. Ne ovat kaksi eri asiaa, vaikka niillä on yhteisiäkin piirteitä, ja vaikka sama ihminen voi olla sekä esittäjä että esiintyjä. Performanssista puhuttaessa ei ole aina ole täsmennetty, mitä kaikkea sillä tarkoitetaan. Selvää on se, että me suomalaistutkijat olemme tutkineet esityksiä, emme esiintymisiä. Seppo Knuuttila on ainoana kirjoittanut esiintymisestä artikkelissaan Pohjois-Karjalan perinne-esiintyjistä (Knuuttila 1989).

Kysynkin nyt, olisiko tutkimuksessa syytä tehdä eroa julkisen kertomisen ja pienemmälle, intiimimmälle kuulijakunnalle kertomisen välillä. Olisiko syytä erottaa esiintyminen ja esitys toisistaan? Ja mihin sijoittuu performanssi? Vaikka sekä esitys että esiintyminen voivat vastata englannin performance-käsitettä, mielestäni termit olisi syytä pitää erillään. Esiintyminen on luonteva käännös performanssille, kun taas esitys on eleetöntä kerrontaa pienryhmälle.

Yritän erottaa toisistaan esityksen ja esiintymisen tuntomerkit:

\section{JULKINEN ESIINTYMINEN}

\section{YKSITYINEN ESITYS}

1. + valmistautuminen

2. + julkinen

3. + estradi/ + kehys

4. $-(+)$ vastavuoroisuus

5. + metakerronta

$$
\begin{aligned}
& \text { - (+) valmistautuminen } \\
& \text { - julkinen } \\
& \text { - estradi / - (+) kehys } \\
& + \text { vastavuoroisuus } \\
& +- \text { metakerronta }
\end{aligned}
$$

1. Valmistautuminen liittyy ilman muuta esiintymiseen, mutta esimerkiksi omat haastattelutilanteeni kertovat siitä, että haastateltava voi valmistautua myös seuraavaa 
haastattelutapaamista varten. Valmistautuminen ei aina paranna haastattelukerrontaa. Esitys voi olla myös spontaani, mutta sen taustalla on harjaantumista, joka tekee kertojasta kompetentin.

2. Esiintymiseen liittyy eriasteista julkisuutta, esitys on yksityisempää.

"Julkisuus" voi tarkoittaa myös sitä, että kertoja toivoo, että hänen sanottavansa leviäisi muidenkin tietoon. Hänellä voi olla esimerkiksi poliittinen tai uskonnollinen sanoma.

3. Esiintymisellä on selvä kehys, jonka avulla kuulijat tunnistavat sen, että kertoja haluaa esiintyä. Kertoja myös nousee joko todelliselle tai asemansa luomalle jalustalle, jota voisi kutsua "estradiksi". Kuulijat hyväksyvät normaalisti sen, että julkisessa esiintymisessä kertoja ottaa dominoivan roolin. Hyväksyessään tämän he asettuvat kuuntelijoiksi. (ks. myös Palmenfelt 2009, 6 [online]). Esitystä ei yhtä selvästi kehystetä, mutta se nousee esiin muusta kerronnasta kielellisin (esimerkiksi aloituspartikkelit ja pronominit) ja paralingvistisin merkitsimin (esimerkiksi tauot, äänen voimakkuuden ja sävyn vaihtelut, puheen tempo ja naurut) (Kaivola-Bregenhøj 1988, 225-227, 314). Nämä merkitsimet ovat korostetusti mukana myös silloin, kun kertoja esiintyy julkisesti.

4. Esiintyminen ei ole normaalisti vastavuoroista, vaikka hyvät lavaesiintyjät tavoittelevat sitä. Esitykseen kuuluu vastavuoroisuus eli kerrontavuorot ja muiden kertojien huomionotto. Ed Bell viittasi tähän puhuessaan nuotiotulien kerrontatilanteista, missä moni kertoja odottaa pääsevänsä esille. Haastattelutilanne on siinä mielessä poikkeava, että kertoja saa halutessaan pitää yksin vuoroa hallussaan.

5. Richard Baumanin sanoin ei ole kertomusta ilman metakerrontaa (Bauman 1986, 98). Taulukossani on plus/miinus esityksen kohdalla siksi, että pohdin voisiko esitys sujua ilman metakerrontaakin. Laura Aro on huomauttanut, että "sisäpiiriläinen tarvitsee vähemmän metakerrontaa pysyäkseen mukana keskustelussa" (Aro 1996, 49). Kaikki tuntevat toisensa ja ovat ehkä kuulleet saman kertomuksen aiemminkin. Myös paralingvistiset keinot, kuten äänenpainot ja ilmeet, voivat toimia metakerrontana (Hovi, suullinen tiedonanto 2009).

Piirteet ovat minun aineistojeni valossa erottelukykyisiä: kun on kyse esiintymisestä, esittävä funktio vie voiton kerronnan muista funktioista, kun taas pienen piirin esityksessä on yleensä informoiva, julistava, uskoutuva tai jokin muu funktio selvemmin esillä (Bauman 1992, 44). Mutta folkloreen liittyy aina "mutta toisaalta" -mahdollisuus. Se kuuluu moni-ilmeisen perinteen tuntomerkkeihin, jotka takaavat sen, että folklore säilyy elinvoimaisena eikä pitkästytä käyttäjiään eikä yleisöä.

Seuraavaksi kysyn: Kannattaisiko pyrkiä tällaiseen erontekoon kahden käsitteen, esityksen ja esiintymisen välillä? Ja mihin sijoitamme kolmannen, performanssin käsitteen, vai pidämmekö sitä kattoterminä? Mielestäni performanssi olisi luonteva esiintymisen synonyymi, ja on turhaa pitää sitä kahden käsitteen kattoterminä. Palaan vielä Baumanin performanssi-termiin esteettisesti kehystettynä ja kohosteisena kommunikaation muotona, joka on tarkoitettu yleisölle (Bauman 1992, 41). Nämä tuntomerkit sopivat esiintymiseen ja joskus tietysti myös esitykseen, ja niiden välisen rajan vetäminen on todellakin hienosäätöä. Toisaalta se, että esimerkiksi vitsi tai 
sananlasku lausutaan ääneen, ei vielä tee siitä performanssia. Performanssi - esiintyminen - on löydettävä ja tunnistettava tapauskohtaisesti.

Eronteko käsitteiden välillä osoittautuu tarpeelliseksi, kun tutkija purkaa omia haastattelutilanteitaan - ja ne ovatkin ainoat, mistä voi varmuudella sanoa jotakin. AnnaLeena ja Jukka Siikala toteavat eteläisten Cookin saarten perinnettä analysoidessaan, että nykypäivän vapaa arkidiskurssi sallii suhteellisen paljon vapaita mielleyhtymiä, kun taas monet niistä tilanteista (engl. perfoming situations), joissa esillä ovat suulliseen perinteeseen kuuluvat kertomukset, ovat tiukemmin kaavamaisia (Siikala \& Siikala 2005, 135). Tunnistan tämän omista haastattelutilanteistani, joista löytyvät raportoiva kuvailu (alalajeineen), esitys ja esiintyminen/ performanssi, ja mielenkiintoista on se, että ne kaikki voivat sisältyä samaankin haastatteluun. Palaan nyt Juho Oksasen kertomuspariin Papit ja politiikka ja seuraan nauhoitustani kuunnellen, miten kertoja tuli tähän kerronnan yksikköön, minkä nimeän tietoiseksi esiintymiseksi. Kyseessä oli toisen haastattelukesän viimeinen nauhoituskerta, ja mukana olivat Oksasen ja minun lisäkseni Pekka Laaksonen sekä Oksasen Tilda-vaimo. Elokuista iltapäivää edelsivät aiemmat tapaamiset päivällispöydässä ja sahtikannun tuntumassa. Kertoja oli hyvässä vedossa ja piti varmaan siitä, että haastattelijoina oli kaksi hänelle tuttua ihmistä. Hän imitoi tapansa mukaan repliikkejä, nyt eloisammin kuin kahdenkeskisessä haastattelussa, jonka nimeän esitykseksi. Jossakin vaiheessa sanoin Oksaselle, että hänpä osaakin mainiosti jäljitellä pappien puheita. Oksanen totesi olleensa 37 vuotta pappien kanssa tekemisissä, suntio kun oli. Sen jälkeen hän totesi: "Ai ai sentäs. Puhunks mä neitin ka[nssa] ... politiik[asta] ... juu se on puhuttu. Polittiikkakin kirkkoo vietii! Ol' se jo män se jo tuolla." Ja samassa alkoi kertomus! Oksanen syttyi aiheelle, vaikka muistikin kertoneensa paria päivää aikaisemmin minulle saman kertomuksen. Mutta nyt Sysmän papeissa polveillut keskustelumme nosti aiheen pintaan, ja uusi kuulijakin oli sopivasti paikalla. Kertoja syttyi ja halusi esiintyä ja kehysti niin sanallisesti kuin paralingvistisin merkitsimin kaskunsa. Ja tämä esiintymisjakso ei ollut ainoa tällä nauhoituskerralla. Dell Hymesin tunnistama koodin vaihto, tässä jutustelusta hallittuun kerrontaan, oli selvästi tunnistettava "breakthrough into full performance" (Hymes 1975, 24).

Mutta ei tässä kaikki. Jotta Papitja politiikeka-kertomus aukeaisi ilmaisun tasolla kuulijalle täysin, hänen on osattava sijoittaa Juho Oksanen Sysmän sosiaalis-kulttuuriseen kontekstiin. Kartanon emännöitsijän aviottomana lapsena syntynyt Oksanen tunsi hyvin Sysmän yhteiskuntaluokkien elämän. Hän oli päätynyt pienviljelijän työnsä ohella suntioksi, mutta vasta toisella hakukerralla kovana sosialistina pidetty mies hyväksyttiin kirkon virkaan. Suntiona hänen oli kuitenkin pakko erota työväenyhdistyksestä (Kaivola-Bregenhøj 1988, 62). Oksanen eli miehuusvuosinaan Sysmän sosiaalisten kerrosten välimaastossa ja seurasi niin seurakunnan kuin kunnallisten luottamustoimiensa näköalapaikoilta kartanoiden väen, pappien, suurtilallisten ja tavallisen kansan edesottamuksia. Tämä antoi särmää hänen moniin paikallishistoriallisiin kertomuksiinsa. Huumoriin kätkeytyi joskus lievää, joskus ankarampaakin kritiikkiä. Esittäessään kulttuurikaskunomaista Papit ja politiikka -kertomusta Oksanen toi ilmaisullaan julki oman kriittisen näkemyksensä tapahtumista. Yleisönä me paikallaolijat olimme osana performanssia - Oksasen voimallista esiintymistä - ja kuuntelimme "erityisen intensiivisesti” (Bauman 1992, 44) hyvin esitettyä kertomusta samoin kuin sen perimmäistä 
sanomaakin. Meidän naurumme oli sekä huvittunutta että ymmärtävää.

Tällä hetkellä kerronnan tutkimuksessa keskitytään aivan muihin kysymyksiin kuin silloin kun Juha Pentikäinen, Anna-Leena Siikala, Laura Aro ja minä kirjoitimme haastatteluaineistoihin perustuvat kertojatutkimuksemme. Monisävyisen esittämisen tutkimus on nyt sivuraiteella, mutta täytyyhän sen taas jossain vaiheessa alkaa kiinnostaa tutkijoita. Virtuaalisten kenttien, kuten sähköpostin, keskustelupalstojen, tukiryhmien tai facebookin tutkimus asettaa tutkijoille uudenlaisia haasteita tunnistettaessa kerronnan ja esittämisen/esiintymisen rekistereitä (Hovi, suullinen tiedonanto 2009). Sitä silmällä pitäen käsitteet ja niihin liittyvät termit on keskusteltava selviksi, sillä niiden avulla kertomusten ja kerronnan analyysiin voi saada uuden otteen. Näin kävi minulle.

\section{LÄHTEET}

\section{Tutkimusaineistot}

Suomalaisen Kirjallisuuden Seura, Äänitearkisto, haastattelijana Annikki KaivolaBregenhøj. SKSÄ 353:28-29.1969.

Suomalaisen Kirjallisuuden Seura, Kansanrunousarkisto

— Kiikka. Hilkka Kesti KT 21:18.1936.

— Kuortane. Helmi Mäkelä AK 12: 467.1967.

\section{Keskustelut}

BREGENHØJ, CARSTEN, suullinen tiedonanto syyskuussa 2007.

HASAN-ROKEM, GALIT, suullinen tiedonanto syyskuussa 1981.

HOVI, TUIJA, suullinen tiedonanto 27.4.2009, Folkloristiikkaa 2000-luvulla -teemapäivänä Turun yliopistossa.

UKKONEN, TAINA, sähköpostikeskustelu maaliskuussa 2008.

\section{Kirjallisuus}

ABRAHAMS, ROGER 1981: The Complex Relations of Simple Forms. - BenAmos, Dan (ed.), Folklore Genres. Austin and London: University of Texas Press. ARO, LAURA 1996: Minä kylässä. Identiteettikertomus haastattelututkimuksen folklorena. Helsinki: SKS.

BAUMAN, RICHARD 1978: Verbal Art as Performance. Series in Sociolinguistics. Rowley, Massachusetts: Newbury House Publishers.

- 1986: Story, Performance, and Event. Contextual Studies of Oral Narrative. Cambridge: Cambridge University Press.

- 1992. Performance. - Bauman, Richard (ed.), Folklore, Cultural Performances and Popular Entertainments. A Communications-Centered Handbook. New York: Oxford 


\section{AnNIKKI KAIVOLA-BREGENHø]}

University Press.

DÉGH, LINDA 1969: Folktales and Society. Story-Telling in a Hungarian Peasant Community. Bloomington: Indiana University Press.

HAAVIO, MARTTI 1948: Viimeiset runonlaulajat. Helsinki: Werner Söderström Osakeyhtiö. HOLTARI, TIMO \& LAAKSONEN, PEKKA \& VENTO, URPO (toim.) 1970: Jätkät senkun porskuttaa. Helsinki: SKS.

HONKO, LAURI 1980: Kertomusperinteen tutkimustavat ja niiden tulevaisuus. Laaksonen, Pekka (toim), Kertojat ja kuulijat. Helsinki: SKS.

HYMES, DELL 1973: Breakthrough into Performance. - Ben-Amos, Dan \& Goldstein Kenneth S. (eds.), Folklore. Performance and Communication. The Hague, Paris: Mouton.

KAIVOLA-BREGENHØJ, ANNIKKI 1988: Kertomus ja kerronta. Helsinki: SKS.

- 2001: Riddles. Perspectives on the Use, Function and Change in a Folklore Genre. Helsinki: SKS.

- 2005: Uusiutuva arvoitusperinne. - Saarikoski, Helena (toim.), Leikkikentiltä. Lastenperinteen tutkimuksia 2000-luvulta. Helsinki: SKS.

- 2006: War as a Turning Point in Life. - Kaivola-Bregenhøj, Annikki \& Klein, Barbro \& Palmenfelt, Ulf (eds.), Narrating, Doing, Experiencing. Nordic Folkloristic Perspectives. Helsinki: SKS.

- 2007: Historia purkautuu kertomuksiksi. - Stark, Eija \& Stark, Laura (toim.), Kansanomainen ajattelu. Helsinki: SKS.

KNUUTTILA, SEPPO 1989: Perinne-esiintyjï Pohjois-Karjalassa. - Knuuttila, Seppo \& Laaksonen, Pekka (toim.), Runon ja rajan teillä. Helsinki: SKS.

PALMENFELT, ULF 2009: Portal: kurser. Muntligt berättande i teori och praktik. Narrativa grundstrukturer [online / ei internetissä vapaasti luettavana]. [2.8.2009.]

PENTIKÄINEN, JUHA 1971: Marina Takalon uskonto. Uskontoantropologinen tutkimus. Helsinki: SKS.

POLANYI, LIVIA 1989: Telling the American Story. A Structural and Cultural Analysis of Conversational Storytelling. Cambridge, Massachusetts: The MIT Press.

SIIKALA, ANNA-LEENA 1980: Personal and Social Meaning of Story-Telling. Ikola, Osmo (toim), Congressus Quintus Internationalis Fenno-Ugristarum. Turku 20.-27. VIII.1980. Pars IV. Turku: Suomen Kielen Seura.

SIIKALA, ANNA-LEENA \& SIIKALA, JUKKA 2005: Return to Culture. Oral Tradition and Society in the Southern Cook Islands. Helsinki: Academia Scientiarum Fennica.

SUOJANEN, MATTI 1996: Kertomukset päivittäisviestinnässä. - Sananjalka 38.

TARKKA, LOTTE 2005: Rajarabvaan laulu. Tutkimus Vuokkiniemen kalevalamittaisesta runokulttuurista 1821-1921. Helsinki: SKS.

UKKONEN, TAINA 2000: Menneisyyden tulkinta kertomalla. Muistelupube oman historian ja kokemuskertomusten tuottamisprosessina. Helsinki: SKS.

VENTO, URPO 1980: Kerronta rituaalina. - Laaksonen, Pekka (toim.), Kertojat ja kunlijat. Helsinki: SKS.

Annikki Kaivola-Bregenhøj on Turun yliopiston em. folkloristiikan professori. Hän jatkaa tutkimustyötään ja on keskittynyt viime aikoina erityisesti kansanomaisiin unenkerronta- ja tulkintaprosesseihin. Työpöydällä on myös kertomuksiin ja kerrontaan sekä arvuutteluperinteisiin liittyviä artikkeleita. 